\title{
Biochar From Feedstock: A Strategy To Improve Agronomic Performances And Microbial Biomass of Tomato (Solanum Lycopersicum I.) Plant.
}

Seun ADEBAJO ( $\square$ adebajoso@funaab.edu.ng )

Federal University of Agriculture

Folasade OLUWATOBI

Federal University of Agriculture

Pius AKINTOKUN

Federal University of Agriculture

Abidemi OJO

Federal University of Agriculture

Ronke AKINTOKUN

Federal University of Agriculture

Ige GBODOPE

Federal University of Agriculture

\section{Research Article}

Keywords: Biochar, Pyrolysis, Tomato, Microbial biomass

Posted Date: September 13th, 2021

DOl: https://doi.org/10.21203/rs.3.rs-842469/v1

License: (c) (i) This work is licensed under a Creative Commons Attribution 4.0 International License.

Read Full License 


\section{Abstract}

Tomato is beneficial to human health because it contains valuable vitamins such as vitamins $A, C$ and several minerals. However, to meet up with the demands of the ever increasing population, there is need to improve tomato production. This research, investigated the impact of biochar derived from rice husk on agronomic performances of tomato plant. The rice husk biochar pyrolysed at $350^{\circ} \mathrm{C}$ was amended with soil at four different application rates: 0, 2.5, 5.0 and 7.5 t/ha. Physicochemical property of soil was conducted using Mid Infrared Reflectance Spectroscopy method. Impact of biochar on Microbial Biomass Carbon, Microbial Biomass Nitrogen and Microbial Biomass Phosphorous was conducted using fumigation extraction method and monitored at three functional stages. Biochar application appreciably increase the soil physicochemical properties such as $\mathrm{pH}, \mathrm{Ca}, \mathrm{Na}, \mathrm{H}+, \mathrm{S}, \mathrm{P}, \mathrm{B}, \mathrm{Zn}$ and cation exchangeable capacity. Biochar amended soil significantly enhanced tomato height, fruit yields and weight. The ratio of Microbial biomass C: N: P for biochar amended soil at $7.5 \mathrm{t} / \mathrm{ha}$ (B3) was $302.30: 18.81: 11.75 \mu \mathrm{g} / \mathrm{g}$, compared to control, which was 242.12: $18.30: 11.49 \mu \mathrm{g} / \mathrm{g}$. This study revealed that biochar amendments significantly $(p<0.05)$ increased the yields and microbial biomass of tomato plant.

\section{Introduction}

Good soil conditions are required to produce high quality plants especially tomato. Tomato (Solanum lycopersicum L.) is a famous vegetable commonly grown in home gardens as larger yield is gotten using a little space. It contains vitamins $\mathrm{A}, \mathrm{C}$ and important minerals particularly $\mathrm{Ca}, \mathrm{Mn}$ and $\mathrm{K}$ (Naika et al., 2005). Acccording to Parray et al. (2007), tomato promotes gastric secretion, act as blood purifier and keep intestines in good condition.

Due to continuous cropping over a long time and excessive application of chemical fertilizers, soil fertility reduces gradually because of erosion and instability of organic matter. This affects the soil and consequently plant quality which in turn brought about lower yield of agricultural crops globally (Foley et al., 2005).

Soil amendment with biochar has been considered to be a cheap and easy method that can be used to stabilise soil fertility and mitigate climate change in order to sequester atmospheric $\mathrm{CO}_{2}$, increase crop yield and lower greenhouse gas emissions such as $\mathrm{CO}_{2}, \mathrm{~N}_{2} \mathrm{O}$ and $\mathrm{CH}_{4}$ (Agegnehu et al., 2017).

Plethora of studies conducted in varying parts of the globe and on different plants have shown that biochar application/amendment affected soil microbial activities and abundance, improved cationic exchange capacity (CEC), pH, nodulation, soil water holding capacity, nutrient availability/intake and plant productivity (Mulabagal et al., 2015, Palansooriya et al., 2019 and Faloye et al., 2020).

Increasing human population and activities reduce the available land resources for tomato production. It is thus imperative to improve the limited land resources to boost and enhance its production. Therefore, this study is aimed at investigating the effects of rice husk biochar amendment on agronomic performances and microbial biomass of tomato plant. 


\section{Materials And Methods \\ Collection of Seeds}

Seeds were obtained from the National centre for Genetic Resource and Biotechnology (NACGRAB) Ibadan, Oyo State, Nigeria.

\section{Site description}

The experiment was carried out at the screened house of College of Biosciences (COLBIOS) of the Federal University of Agriculture, Abeokuta, Ogun State, South western Nigeria (Latitude $7^{\circ} 15^{\prime} \mathrm{N}$, Longitude $3^{\circ} 25^{\prime}$ E and annual rainfall $963.3 \mathrm{~mm})$.

\section{Experimental design}

The experimental design was a completely randomised design in the greenhouse. The experiment consists of 4 treatments, that is the Control (no biochar), biochar amendment rate at $2.5 \mathrm{t} / \mathrm{ha}$ (B1), 5.0 $\mathrm{t} / \mathrm{ha}$ (B2) and $7.5 \mathrm{t} / \mathrm{ha}$ (B3). Each treatment was replicated in 3 pots making a total of 12 pots and two Beske tomato seeds were transplanted per pot from the nursery.

\section{Biochar and soil sampling}

Biochar was prepared according to the model reported by Bob Wells. A modified biochar kiln was developed (Bob Wells, 2013). The rice husk feedstock was pyrolysed at $350^{\circ} \mathrm{C}$. The resulting biochar was ground to pass it through a $2 \mathrm{~mm}$ sieve before application to the soil.

The top soil sample of depth $0-15 \mathrm{~cm}$ was randomly collected from the Teaching and Research Farm of the Federal University of Agriculture, Abeokuta, Ogun state. The soils of the area were generally sandy loam type which makes it adequate for the study. Each $5 \mathrm{~kg}$ bucket of soil was mixed homogenously with biochar. Five weeks old tomato seedlings were transplanted from the nursery to soil amended with biochar and control.

\section{Physicochemical analysis of soil}

Physical and chemical analysis of soil was conducted using Mid Infrared Reflectance Spectroscopy as conducted by Ojo et al. (2017).

\section{Agronomic parameters}

Agronomic parameters of tomato plant such as plant height $(\mathrm{cm})$, stem girth $(\mathrm{mm})$, number of fruits and leaf areas were recorded as described by Chaudhary et al. (2012). One-hundred grams of soil adhering to the roots of the plant was collected in sterilized plastic bags for analysis. The soil samples were collected at three functional stages: Vegetative, Flowering and Maturity/harvesting stages.

\section{Microbial Biomass}


The impact of biochar on Microbial Biomass Carbon (MBC), Microbial Biomass Nitrogen (MBN) and Microbial Biomass Phosphorous (MBP) was conducted using fumigation extraction method (Zhang et al., 2014).

\section{Statistical Analysis}

Statistical analysis was performed using SPSS version 20.0. The statistical significance of differences between treatments was determined by one way analysis of variance (ANOVA) followed by Duncan's test with $(p<0.05)$.

\section{Results}

\section{Soil Physicochemical and Chemical Properties of Rice Husk Feedstock (RHF) and Rice Husk Biochar (RHB).}

The physicochemical property of the soil Before Biochar Amendment (BBA) in control and After Biochar Amendment (ABA) at B3 showed that the soil used was sandy loamy soil. The Effective Cation Exchange Capacity (E.CEC), nitrogen, \% total Carbon (TC) and pH of soil were $4.11 \mathrm{cmol} / \mathrm{kg}, 0.09,0.74$ and 6.28 respectively before biochar amendment. Slight increase was observed (except in silt, $\mathrm{Mg}$ and Fe) after biochar amendment at B3. The pH of RHF (6.84) increased to 7.86 in RHB. The values of Ca, Mg, K, E.CEC and $P$ increased appreciably while slight increase was observed in the values of $B, Z n$ and $\mathrm{Si}$. The values of $\mathrm{H}^{+}, \mathrm{Na}, \mathrm{S}, \%(\mathrm{TC})$, Total Nitrogen (TN), N, Mn, Cu and Fe decreased in biochar than the biomass (Table 1). 
Table 1

The physicochemical properties of the soil before and after biochar amendment; chemical properties of rice husk feedstock and biochar.

\begin{tabular}{|c|c|c|c|c|}
\hline Properties & BBA & $\mathrm{ABA}$ & RHF & RHB \\
\hline Sand (\%) & 64.88 & 65.09 & - & - \\
\hline Clay (\%) & 16.63 & 24.74 & - & - \\
\hline Silt (\%) & 18.48 & 18.48 & - & - \\
\hline E.CEC (cmol/ $/ \mathrm{kg})$ & 4.11 & 5.21 & 11.61 & 13.72 \\
\hline $\mathrm{pH}$ & 6.28 & 6.35 & 6.84 & 7.86 \\
\hline $\mathrm{Ca}(\mathrm{cmol} / \mathrm{kg})$ & 2.45 & 3.95 & 6.75 & 8.24 \\
\hline $\mathrm{Mg}$ (cmol/kg) & 0.82 & 1.24 & 3.52 & 6.29 \\
\hline $\mathrm{K}(\mathrm{cmol} / \mathrm{kg})$ & 0.47 & 0.36 & 95.04 & 97.40 \\
\hline $\mathrm{Na}(\mathrm{cmol} / \mathrm{kg})$ & 0.27 & 0.37 & 0.34 & 0.21 \\
\hline $\mathrm{H}^{+}$ & 0.10 & 0.11 & 0.09 & 0.05 \\
\hline S (mg/kg) & 5.28 & 6.33 & 30.7 & 16.06 \\
\hline$P(\mathrm{mg} / \mathrm{kg})$ & 4.14 & 5.08 & 32.37 & 102.87 \\
\hline B (mg/kg) & 0.04 & 0.06 & 0.18 & 0.19 \\
\hline$\%$ Total C & 0.74 & 0.84 & 6.59 & 3.70 \\
\hline$\%$ Total N & 0.09 & 0.13 & 0.24 & 0.19 \\
\hline $\mathrm{Mn}(\mathrm{mg} / \mathrm{kg})$ & 57.22 & 54.89 & 25.15 & 21.35 \\
\hline $\mathrm{Cu}(\mathrm{mg} / \mathrm{kg})$ & 0.85 & 1.28 & 2.48 & 1.60 \\
\hline $\mathrm{Fe}(\mathrm{mg} / \mathrm{kg})$ & 151.60 & 99.40 & 35.25 & 14.90 \\
\hline Zn (mg/kg) & 1.08 & 1.10 & 1.16 & 1.17 \\
\hline Si (mg/kg) & - & - & 36.20 & 36.23 \\
\hline
\end{tabular}

\section{Effect of rice husk biochar on tomato height}

The application of rice husk biochar with the soil significantly $(p<0.05)$ influenced the plant height at all the growth stages: 6th, 8th, 10th and 12th Week after Transplanting (WAT). All the treatments were significantly $(p<0.05)$ different from one another across the week compared to control. At 6 th, 10 th and 
12th WAT, the treatment that received treatment B1 and B3 had the highest tomato height while the control recorded the lowest tomato height (Fig. 1).

\section{Effect of biochar on tomato stem girth}

In the treatments at 6th and 10th WAT, there was no statistical difference observed but at 8th WAT and 12th WAT, significant difference in stem girth was observed. Moreover, the amendment of biochar of rates B1 to B3 significantly $(p<0.05)$ enhanced the mean values of tomato stem girth throughout the weeks after transplanting. B1 had highest mean values of tomato stem girth 10th and 12th WAT. However, the control experiment showed the lowest mean values of tomato stem girth (Fig. 2).

\section{Effect of biochar on tomato leaf area}

Results revealed statistical difference among the treatments and control at all the WAT. The addition of biochar significantly increased length and breadth of the tomato leaves at all the weeks after transplanting compared with the control experiment, except B2 at 10 and 12 WAT (Fig. 3).

\section{Effect of biochar on number of tomato flowers}

Sprouting of flowers started at 8th WAT in all treatments. All the treatments were significantly $(p<0.05)$ different from one another. At 8th WAT to 12th WAT, it was observed that treatment B3, performed better in promoting the sprouting of tomato flowers, compared to other rates. The control had the lowest number of flowers across the weeks (Fig. 4).

\section{Effect of biochar on tomato yield}

No significant difference was observed except in the treatment that received B2 rate of biochar at 12WAT after the experiment. Treatment B3 had highest positive influence on the yield of tomato all through the weeks compared to other treatments and the control (Fig. 5).

\section{Effect of biochar on weight of tomato fruits}

The addition of biochar significantly $(p<0.05)$ enhanced the weight of tomato plant after harvesting. The treatment that received B3 recorded the highest weight $(54.21 \mathrm{~g}=40 \%)$, followed by B1 $(42.81 \mathrm{~g}=32 \%)$ and B2 $(26.48 \mathrm{~g}=20 \%)$ compared to the control experiment $(10.21 \mathrm{~g}=8 \%)($ Fig. 6$)$.

\section{Effects of different rates of biochar on microbial biomass (Carbon, Nitrogen and Phosphorous)}

The amendment of biochar at all rates significantly enhanced the performance of tomato plants. All the treatments at every stage in all the microbial biomass were not significantly different from one another. Biochar amendment at different rates was observed to have similar positive influence on all the values of plant soil microbial biomass. Carbon had greater significant effect on the plants compared to microbial biomass nitrogen and phosphorus. 
At harvesting stage in MBN, MBC and MBP, B3 had the highest values which include 302.30, 18.81 and11.75 $\mu \mathrm{gg}-1$ respectively, followed by B2 and B1 while the Control showed the lowest values which include $275.45,15.30$ and $10.49 \mu \mathrm{gg}-1$ respectively (Table 2 ).

Table 2

Effects of different rates of biochar on Microbial Biomass (Carbon, Nitrogen and Phosphorous)

\begin{tabular}{|c|c|c|c|c|}
\hline $\begin{array}{l}\text { Treatments/ } \\
\text { stages }\end{array}$ & Control & $\mathrm{B} 1=2.5 \mathrm{t} / \mathrm{ha}$ & $\mathrm{B} 2=5.0 \mathrm{t} / \mathrm{ha}$ & B3 $=7.5 \mathrm{t} / \mathrm{ha}$ \\
\hline \multicolumn{5}{|c|}{ Microbial Biomass Carbon } \\
\hline $\begin{array}{l}\text { Vegetative } \\
\text { Stage }\end{array}$ & $\begin{array}{l}239.60 \pm \\
0.00^{b}\end{array}$ & $276.00 \pm 0.60^{b}$ & $\begin{array}{l}277.46 \pm \\
1.41^{b}\end{array}$ & $278.00 \pm 0.80^{b}$ \\
\hline $\begin{array}{l}\text { Flowering } \\
\text { Stage }\end{array}$ & $\begin{array}{l}242.12 \pm \\
0.00^{b}\end{array}$ & $288.20 \pm 6.01^{b}$ & $\begin{array}{l}292.78 \pm \\
4.03^{b}\end{array}$ & $\begin{array}{l}296.43 \pm \\
12.40^{\mathrm{b}}\end{array}$ \\
\hline $\begin{array}{l}\text { Harvesting } \\
\text { Stage }\end{array}$ & $\begin{array}{l}275.45 \pm \\
0.00^{b}\end{array}$ & $295.00 \pm 2.60^{b}$ & $\begin{array}{l}297.80 \pm \\
5.42^{b}\end{array}$ & $302.30 \pm 7.60^{b}$ \\
\hline
\end{tabular}

Microbial Biomass Nitrogen

$\begin{array}{lcccc}\begin{array}{l}\text { Vegetative } \\ \text { Stage }\end{array} & 14.83 \pm 0.00^{\mathrm{a}} & 14.71 \pm 0.57^{\mathrm{a}} & 15.61 \pm 0.60^{\mathrm{a}} & 15.75 \pm 0.67^{\mathrm{a}} \\ \begin{array}{l}\text { Flowering } \\ \text { Stage }\end{array} & 14.83 \pm 0.00^{\mathrm{a}} & 17.02 \pm 1.66^{\mathrm{a}} & 17.90 \pm 0.86^{\mathrm{a}} & 18.00 \pm 0.96^{\mathrm{a}} \\ \begin{array}{l}\text { Harvesting } \\ \text { Stage }\end{array} & 15.30 \pm 0.00^{\mathrm{a}} & 18.37 \pm 0.71^{\mathrm{a}} & 18.60 \pm 0.70^{\mathrm{a}} & 18.81 \pm 0.65^{\mathrm{a}} \\ & & & & \end{array}$

Microbial Biomass

Phosphorus

\begin{tabular}{lcccc}
$\begin{array}{l}\text { Vegetative } \\
\text { Stage }\end{array}$ & $9.44 \pm 0.00^{\mathrm{a}}$ & $9.82 \pm 0.26^{\mathrm{a}}$ & $10.01 \pm 0.18^{\mathrm{a}}$ & $10.50 \pm 0.08^{\mathrm{a}}$ \\
$\begin{array}{l}\text { Flowering } \\
\text { Stage }\end{array}$ & $9.86 \pm 0.00^{\mathrm{a}}$ & $10.05 \pm 1.65^{\mathrm{a}}$ & $10.10 \pm 0.57^{\mathrm{a}}$ & $10.58 \pm 0.61^{\mathrm{a}}$ \\
$\begin{array}{l}\text { Harvesting } \\
\text { Stage }\end{array}$ & $10.49 \pm 0.00^{\mathrm{a}}$ & $11.00 \pm 0.57^{\mathrm{a}}$ & $11.35 \pm 0.26^{\mathrm{a}}$ & $11.75 \pm 0.41^{\mathrm{a}}$ \\
\hline
\end{tabular}

Means with the same letter in each column of the microbial biomass are not significantly different at $\mathrm{p}<0.05$, All values in $\mu \mathrm{gg}^{-1}$

\section{Discussion}

Biochar is a by-product of feedstock pyrolysis and is used as a carbon-rich amendment to improve soil physicochemical quality (Lehman and Joseph, 2009). From this study, application of rice husk biochar reduced soil acidity and it is in congruent with the earlier studies of Ghorbani et al. (2019) and Wu et al. 
(2020). This could be attributed to the alkalinity nature of biochar and specifically the increased buffering capacity of soil pH which culminated into improved plant growth (Guo et al., 2016).

Biochar has been reported to be superior to lime in reducing the effect of soil acidity, fruit quality and improving soil characteristics (Wu et al., 2020), its rich in organic carbon, active functional groups and special structure which enhance its ability to react and bind with toxic metals (Khan et al., 2017).

The E.CEC of the soil, basic cations and micronutrient values were elevated after biochar application. This is important as biochar cation exchange capacity (CEC) is germane in helping soil to retain nutrients, reduce fertilizer runoff, and improve soil water retention (Kharel et al., 2019). The increase in CEC and other properties have to do with the level of minerals present in the biomass or feedstock (Khan et al., 2017). This may also be attributed to considerable variation observed in the values of some of the elements like Manganese, Sodium, $\mathrm{H}^{+}$and Copper.

However, \% total carbon in biochar (3.70) was observed to be lower than the one present in the feedstock (6.59). This agrees with previous reports that during a slow pyrolysis, biochar helps in sequestering $50 \%$ of the initial carbon in comparison to low amount retained after pyrolysis (Mulabagal et al., 2015).

Biochar application at B1, B2 and B3 revealed significant increase in tomato height and stem girth across the weeks after transplanting compared to control. There were also significant differences in the leaf area and number of fruits at different biochar application rates compared to control. This is congruent with previous studies on tomato where biochar amendment was reported to reduce transient sodium ions by adsorption and released mineral nutrients such as potassium, calcium, and magnesium into the soil solution, which in turn have the potential in ameliorating salt stress and enhancing tomato production (She et al., 2018).

The role of biochar in improving soil quality and tomato production highlights the importance of biochar as a soil amendment to improve soil properties, particularly soil aggregation, soil biophysical properties, sink for atmospheric $\mathrm{CO}_{2}$, reduced nitrate leaching that ensure environmental sustainability (Ghorbani et al., 2019, Rahman et al., 2020).

Biochar amendments significantly increased the number of flower and fruits progressively at all growth rates at 12WAT. Thus, increasing the yield or tomato production. This is in line with earlier study that biochar application enhanced crop yield especially maize and tomato (Faloye et al., 2020 and Ronga et al., 2020).

Fruit weight is one of the most important parameters contributing in tomato yield. However, it was observed that the weight of tomato plant that received the biochar application at rate B3 (7.5 t/ha) greatly improved in comparison with the control. This agrees with previous study by Ronga et al. (2020) who observed higher mean value of fruit weight in tomatoes $(82.67 \mathrm{~g})$ when biochar fertilizer was used compared to the control $(65.33 \mathrm{~g})$. 
Moreover, biochar amendment at B3 had highest influence on microbial biomass carbon, nitrogen and phosphorus at harvesting stage (302.30, 18.81 and $11.75 \mu \mathrm{g} / \mathrm{g}$ ) compared to control $(275.45,15.30$ and $10.49 \mu \mathrm{g} / \mathrm{g}$ respectively). The change in MBC shows the process of microbial growth, death and organic matter degradation. This is also applicable to microbial biomass nitrogen (MBN) and phosphorous (MBP) as biochar amendment had positive influence on nitrogen and phosphorous. The increase in MBC compared to decrease in MBN at harvesting stage indicated that biochar in soil acted as a carbon source rather than a nitrogen source for soil microbes and this could have consequences on nitrogen cycling (Zhang et al., 2014). Biochar treatment at B3 showed higher value of soil microbial biomass C: N: P ratios i.e. $M B C>M B N>M B P$ and this could be attributed to the report that biochar could decrease the fraction of biomass nitrogen and phosphorous mineralized.

\section{Conclusion}

The findings in this research revealed that rice husk biochar amendment significantly $(p<0.05)$ enhanced the agronomic performances of the screened house tomato plant majorly at B3 (7.5 t/ha). Moreover, it was observed that microbial biomass $\mathrm{C}$ : $\mathrm{N}$ : $\mathrm{P}$ ratio for biochar amended soil at $\mathrm{B} 3$ ( $7.5 \mathrm{t} / \mathrm{ha})$ progressively increased (302.30: 18.81: $11.75 \mu \mathrm{g} / \mathrm{g}$ ) compared to that of control (275.45: 15.30: 10.49 $\mathrm{gg} / \mathrm{g}$ ). Thus, rice husk biochar amendment at B3 (7.5 t/ha) thereby improved growth of tomato plants which could invariably improve tomato production and as well overcome the problems of inorganic fertilizers.

\section{Declarations}

\section{Acknowledgements}

The authors thank the National centre for Genetic Resource and Biotechnology (NACGRAB) for providing the tomato seeds used for the study.

Experimental research and field studies on plants comply with relevant institutional, national and international guidelines and legislation

\section{Funding}

No fund

\section{Conflicts of interest}

Authors declare that they have no conflict of interest

\section{Availability of data and material}

The authors declare that all relevant data supporting the findings of this study are included in this article

\section{Authors' contributions}


ASO, APO and OAE conceived and designed the study. ASO, OF, APO, AAK and GIS carried out most of the field laboratory work. APO, ASO, OAE and GIS analysed and interpreted the data. OAE, AAK and OF helped in writing the original draft. All authors reviewed the manuscript.

\section{Ethics approval}

\section{Not applicable}

\section{Consent to participate}

Not applicable

\section{Consent for publication}

Not applicable

\section{References}

1. Agegnehu G, Srivastava A K, Bird M I (2017) The role of biochar and biochar- compost in improving soil quality and crop performance: a review. Applied Soil Ecology. 119:156-170.

2. BobWells. (2013) Back to Backyard Biochar. New England Biochar. Livingwebfarms.org.

3. Chaudhary A N, Godara S, Cheeran A N and Chaudhari A K (2012) Fast and accurate method for leaf area measurement. International Journal of Computer Application 49 (9): 8887-8975.

4. Faloye OT, Ajayi A E, Alatise M O, Ewulo B S and Horn R (2020) Nutrient uptake, maximum yield production, and economic return of maize under deficit irrigation with biochar and inorganic fertiliser amendments. Biochar: 1-14.

5. Foley J A, DeFries R, Asner G P, Barford C, Bonan G, Carpenter S R, Chapin F S, Coe MT, Daily G C, Gibbs H K and Helkowski J H (2005) Global consequences of land use. Science 309(5734): 570-574.

6. Ghorbani M, Asadi H and Abrishamkesh S (2019) Effects of rice husk biochar on selected soil properties and nitrate leaching in loamy sand and clay soil. International soil and water conservation research 7(3): 258-265.

7. Guo C, Pan Z and Peng S (2016). Effect of biochar on the growth of Poncirus trifoliata (L.) Rafseedlings in Gannan acidic red soil. Soil Science and Plant Nutrition 62: 1-7.

8. Kharel G, Sacko O, Feng X, Morris J. R, Phillips C L, Trippe K and Lee J W (2019) Biochar Surface Oxygenation by Ozonization for Super High Cation Exchange Capacity. ACS Sustainable Chemistry \& Engineering 7(19):16410-16418.

9. Khan KY, Ali B, Cui X Q, Feng Y, Yang X and Stoffella P J (2017) Impact of different feedstocks derived biochar amendment with cadmium low uptake affinity cultivar of pakchoi Brassica rapa sb. chinensis L. on phytoavoidation of $\mathrm{Cd}$ to reduce potential dietary toxicity. Ecotoxicology Environment and Safety 141: 129-138. 
10. Naika S, Juede J, Goffau M, Hilmi M and Dam V (2005) Cultivation of tomato production, processing and marketing. Agromisa/CTA. Revised Edition, 2005 Agrodokseries No 17.

11. Ojo A O, Olalekan O O, Ande O T, Are K S, Adelana A O, Denton A O and Oyedele A O (2017) Comparative study of the Mid infrared spectroscopy and chemical method for soil physical and chemical properties. Ife Journal of Agriculture 29(1): 52-62.

12. Palansooriya K N, Wong J TF, Hashimoto Y, Huang L, Rinklebe J, Chang SX, Bolan N, Wang H and Ok Y S (2019) Response of microbial communities to biochar-amended soils: a critical review. Biochar 1(1): 3-22.

13. Parray B A, Ganai A M and Fazili K M (2007) Physicochemical parameter and growth yield of tomato: role of farmyard manure and neemcake. American-Eurasian Journal of Agric and Environmental Science. 2: 303-307.

14. Ronga D, Caradonia F, Parisi M, Bezzi G, Parisi B, Allesina G, Pedrazzi S and Francia E (2020) Using Digestate and Biochar as Fertilizers to Improve Processing Tomato Production Sustainability. Agronomy 10:138; doi: 10.3390/agronomy10010138.

15. She D, Sun X, Gamareldawla A H, Nazar E A, Hu W and Edith K (2018) Benefits of soil biochar amendments to tomato growth under saline water irrigation. Scientific reports 8(1): 1-10.

16. Wu W, Yang M, Feng Q, McGrouther K, Wang H and Chen Y (2012) Chemical characterization of rice straw-derived biochar for soil amendment. Biomass and Bio energy 47:268 -76.

17. Wu S, Zhang Y, Tan Q, Sun X, Wei W and Hu C (2020). Biochar is superior to lime in improving acidic soil properties and fruit quality of Satsuma mandarin. Science of the Total Environment, 136722.

18. Zhang QZ, Dijkstra F A, Liu X, Wang Y, Huang J and Lu N (2014) Effects of Biochar on Soil Microbial Biomass after Four Years of Consecutive Application in the North China Plain. PLOS ONE 9(7):102062. doi:10.1371/journal.pone.0102062

19. Zhang K, Chen L, Li Y, Brookes PC, Xu J, Luo Y (2017) The effects of combinations of biochar lime and organic fertilizer on nitrification and nitrifiers. Biology of Fertile. Soils 53: 77-87

20. Mulabagala V, Baah D A, Egiebor N O and Chen WY (2015) Biochar from Biomass: A Strategy for Carbon Dioxide Sequestration, Soil Amendment, Power Generation, and $\mathrm{CO}_{2}$ Utilization. Handbook of Climate Change Mitigation and Adaptation DOI 10.1007/978-1-4614-6431-0_80-1\#Springer Science+Business Media New York.

\section{Figures}




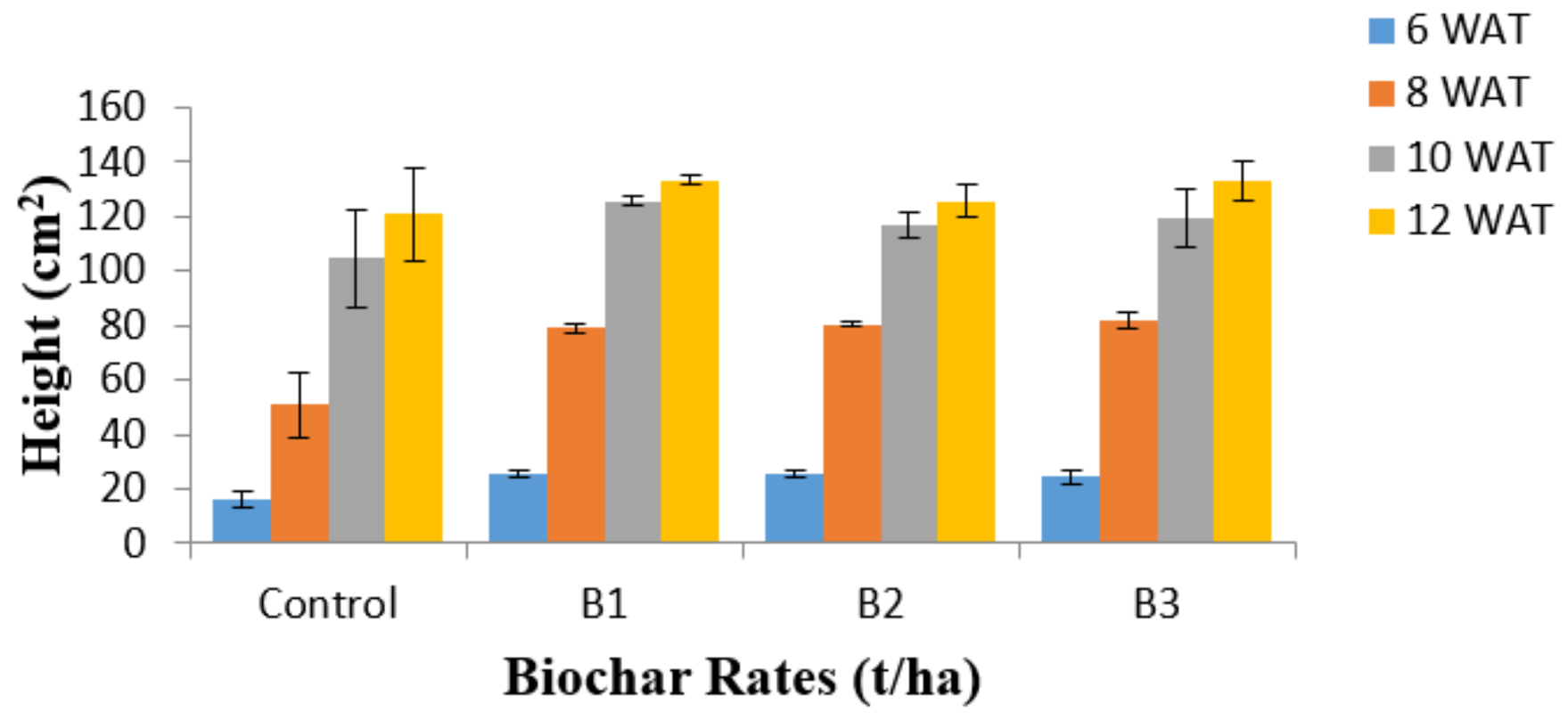

Figure 1

Impact of different rates of biochar on the height $(\mathrm{cm} 2)$ of tomato plant at different weeks of planting. B1 $=2.5 \mathrm{t} / \mathrm{ha}, \mathrm{B} 2=5.0 \mathrm{t} / \mathrm{ha}, \mathrm{B} 3=7.5 \mathrm{t} / \mathrm{ha}$ and WAT $=$.Weeks After Transplanting

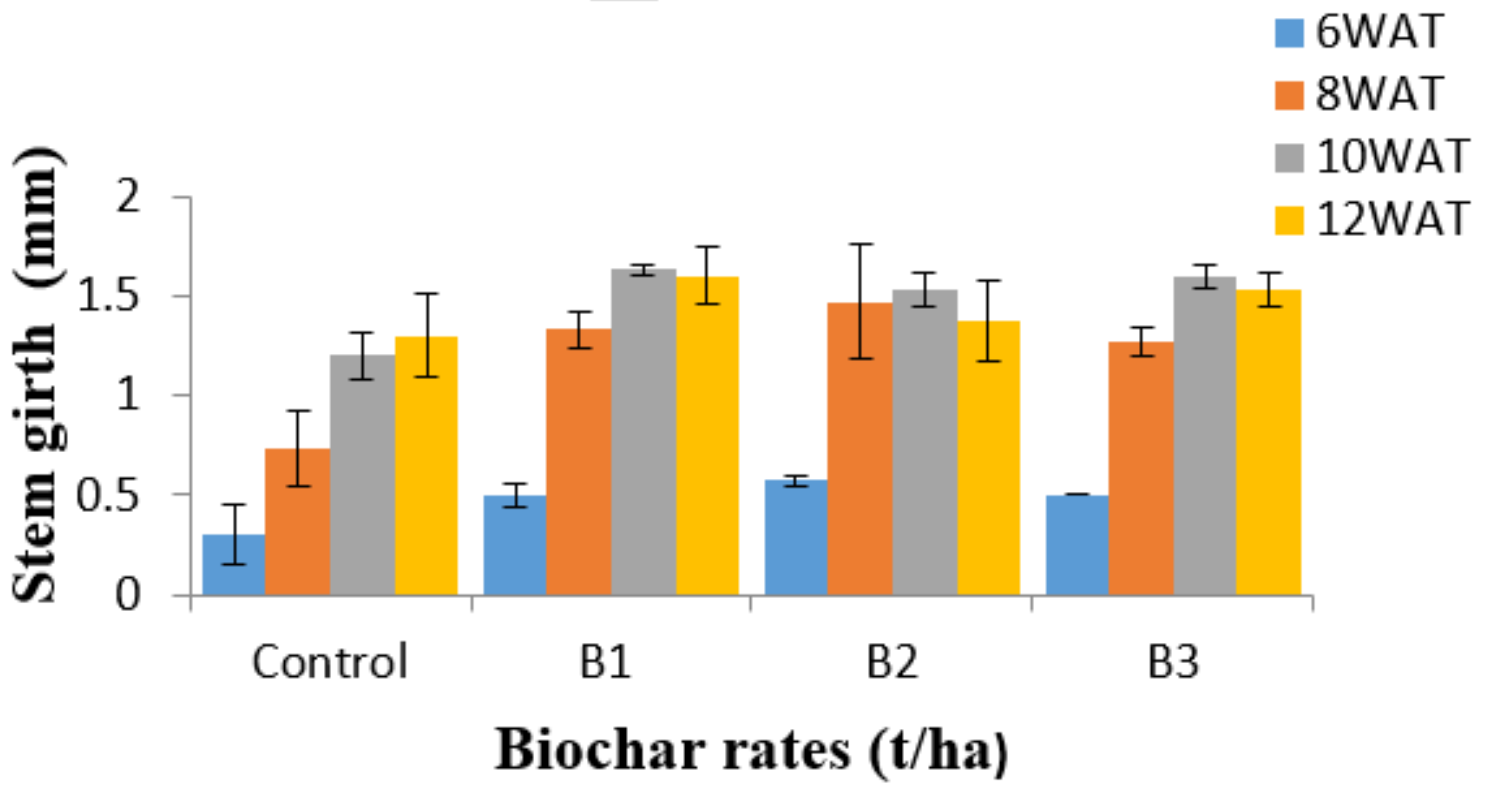

Figure 2

Impact of different rates of biochar on tomato stem girth $(\mathrm{mm})$ at different weeks of planting, $B 1=2.5$ $\mathrm{t} / \mathrm{ha}, \mathrm{B} 2=5.0 \mathrm{t} / \mathrm{ha}, \mathrm{B} 3=7.5 \mathrm{t} / \mathrm{h}$ and WAT $=$. Weeks After Transplanting 


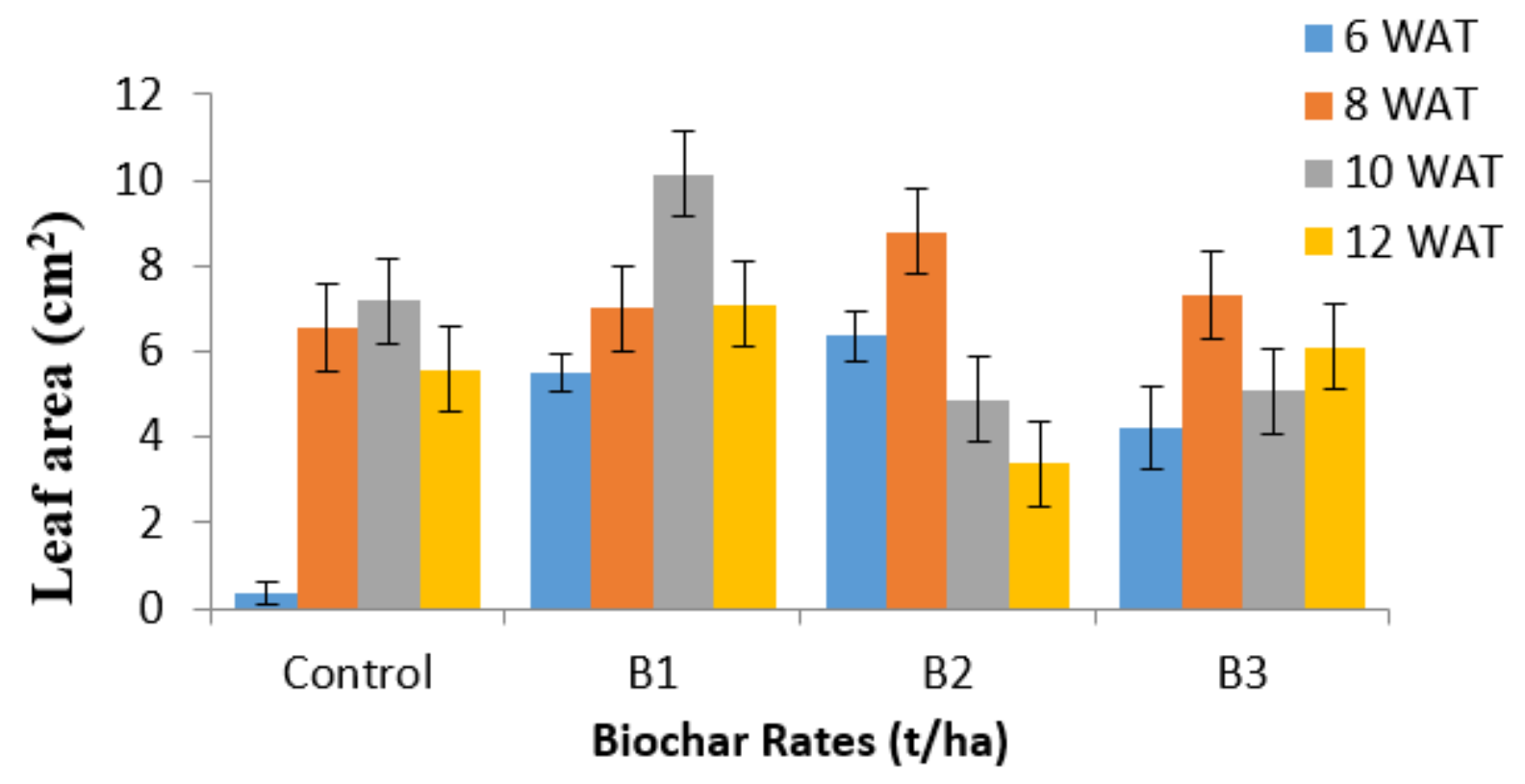

Figure 3

Impact of different rates of biochar on Leaf area $(\mathrm{cm} 2)$ of tomato at different weeks of planting. B1= 2.5 $\mathrm{t} / \mathrm{ha}, \mathrm{B} 2=5.0 \mathrm{t} / \mathrm{ha}, \mathrm{B} 3=7.5 \mathrm{t} / \mathrm{h}$ and WAT $=$.Weeks After Transplanting

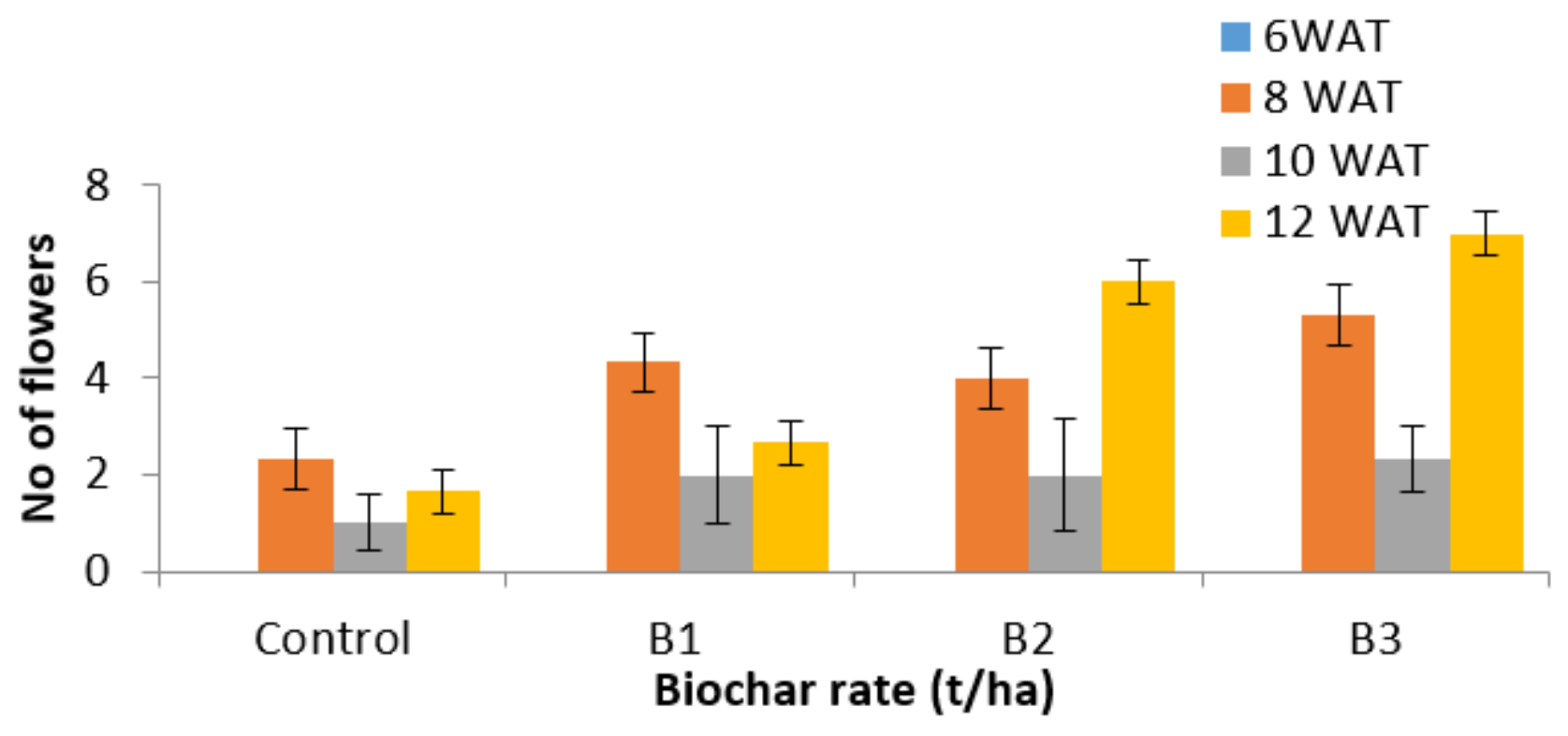

Figure 4

Effect of different rates of biochar on the number of flowers of tomato at different weeks of planting. B1= $2.5 \mathrm{t} / \mathrm{ha}, \mathrm{B} 2=5.0 \mathrm{t} / \mathrm{ha}, \mathrm{B} 3=7.5 \mathrm{t} / \mathrm{h}$ and WAT $=$.Weeks After Transplanting 


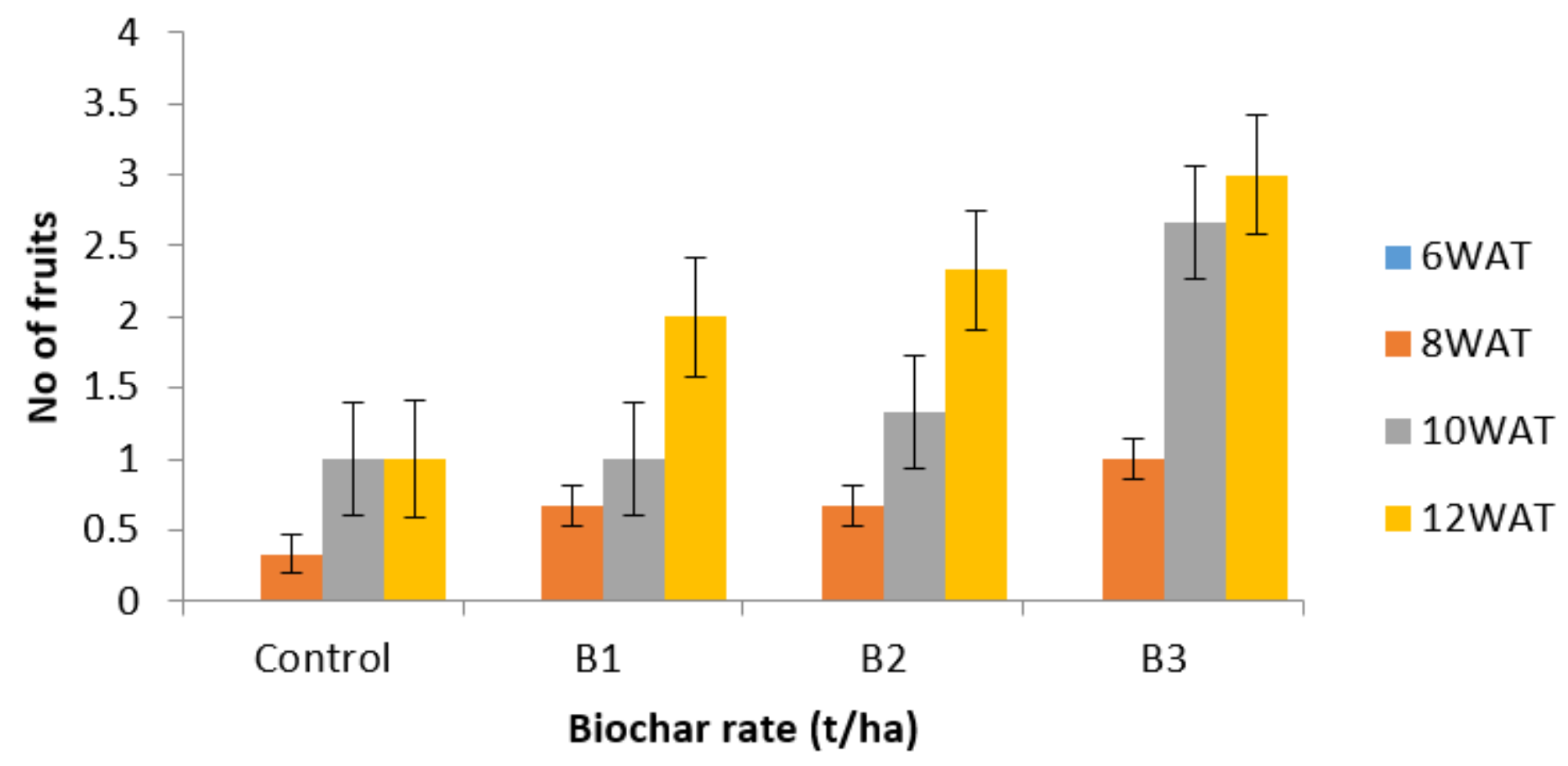

Figure 5

Effect of different rates of biochar on the number tomato fruits at different weeks of planting. B1 $=2.5$ $\mathrm{t} / \mathrm{ha}, \mathrm{B} 2=5.0 \mathrm{t} / \mathrm{ha}, \mathrm{B} 3=7.5 \mathrm{t} / \mathrm{h}$ and WAT $=$. Weeks After Transplanting

\section{Weight}

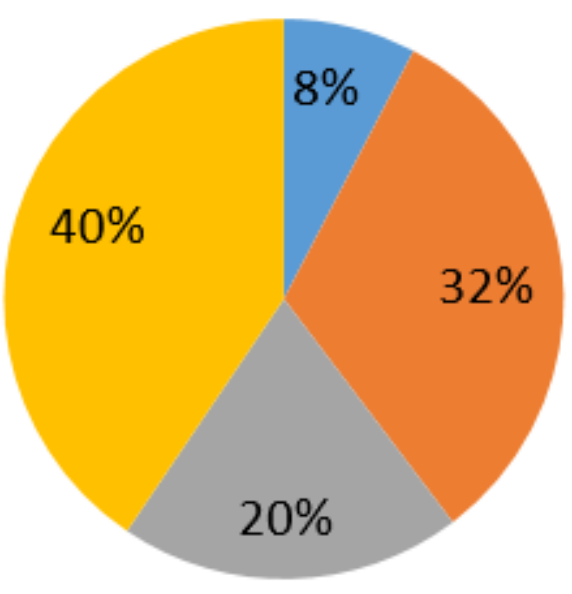

Control

B1

B2

B3

Figure 6

Percentage impact of different biochar rates on weight of tomato at 12 WAT B1 $=2.5 \mathrm{t} / \mathrm{ha}, \mathrm{B} 2=5.0 \mathrm{t} / \mathrm{ha}$ and B3 $=7.5 \mathrm{t} / \mathrm{ha}$ 